\title{
Adaptation of Cucumber Seedlings to Low Temperature Stress by Reducing Nitrate to Ammonium During It's Transportation
}

\section{Yumei Liu}

Chinese Academy of Agricultural Sciences Institute of Vegetables and Flowers

\section{Longqiang Bai}

Shanxi Agricultural University

\section{Jun Wang}

Chinese Academy of Agricultural Sciences

\section{Mintao Sun}

Chinese Academy of Agricultural Sciences

\section{Shuzhen Li}

Chinese Academy of Agricultural Sciences

\section{Li Miao}

Chinese Academy of Agricultural Sciences

\section{Yan Yan}

Chinese Academy of Agricultural Sciences

\section{Chaoxing He}

Chinese Academy of Agricultural Sciences

Xianchang Yu ( $\nabla$ yuxianchang@caas.cn )

Y Liu, M Sun, J Wang, L Miao, Y Yan, C He, X Yu and Y Li, The Institute of Vegetables and Flowers, Chinese Academy of Agricultural Sciences, Beijing 100081, China.

\section{Li Yansu}

IVFCAAS

\section{Research article}

Keywords: cucumber, low temperature, nitrate, ammonium, transportation

Posted Date: November 4th, 2020

DOl: https://doi.org/10.21203/rs.3.rs-100132/v1

License: (c) (1) This work is licensed under a Creative Commons Attribution 4.0 International License. Read Full License 
Version of Record: A version of this preprint was published at BMC Plant Biology on April 19th, 2021. See the published version at https://doi.org/10.1186/s12870-021-02918-6. 


\section{Abstract}

Background: Low temperature seriously depressed the uptake, translocation from root to shoot and metabolism of nitrate and ammonium in thermophilic plants such as cucumber, and the growth of plant was inhibited accordingly. However, there was no breakthrough in the effect of low temperature on nitrogen transport over the years.

Results: By using the non-invasive micro-test technology the net $\mathrm{NO}_{3}{ }^{-}$and $\mathrm{NH}_{4}{ }^{+}$fluxes rate in root hair zone and vascular bundles of main root, stem, petiole, midrib, lateral vein, and shoot tip of cucumber seedlings under normal temperature (NT) and low temperature (LT) treatment were tested, respectively. Under LT treatment, the net $\mathrm{NO}_{3}{ }^{-}$flux rate in root hair zone and vascular bundles of cucumber seedlings decreased, while the net $\mathrm{NH}_{4}{ }^{+}$flux rate in vascular bundles of midribs, lateral veins and shoot tips increased. In accordance with this, the relative expression of CSNRT1.4a in petioles and midribs was down-regulated, while the expressions of CSAMT1.2a 1.2c in midribs were up-regulated. The results of

${ }^{15} \mathrm{~N}$ isotope tracing showed that compared with $\mathrm{NT}$ treatment, $\mathrm{NO}_{3}{ }^{-}-\mathrm{N}$ and $\mathrm{NH}_{4}{ }^{+}-\mathrm{N}$ uptake of the seedlings under LT treatment decreased $78.1 \%$ and $58.8 \%$, respectively, and the concentration and proportion of both $\mathrm{NO}_{3}{ }^{-}-\mathrm{N}$ and $\mathrm{NH}_{4}{ }^{+}-\mathrm{N}$ distributed in the shoot decreased. Under $\mathrm{LT}$ treatment, the actual nitrate reductase activity (NRA $\mathrm{act}_{\text {ct }}$ ) in roots didn't change significantly, while $\mathrm{NRA}_{\mathrm{act}}$ in stems and petioles of LT treatment increased by $113.2 \%$ and $96.2 \%$, respectively.

Conclusion: In summary, the higher net $\mathrm{NH}_{4}{ }^{+}$flux rate in leaves and young tissues may be due to the higher $\mathrm{NR}_{\text {act }}$ in stems and petioles, which could reduce more $\mathrm{NO}_{3}{ }^{-}$to $\mathrm{NH}_{4}{ }^{+}$so as to reduce the energy consumption in nitrogen transportation under low temperature.

\section{Background}

Cucumber (Cucumis stivus L.) is an important vegetable crop worldwide and model system for sex determination and vascular biology [1]. It is native to the tropics and is sensitive to low temperature [2]. Cucumber is widely cultivated in greenhouses in northern China during the winter and spring seasons. Low temperature is one of the major environmental factors that limit the development and productivity of cucumber [3].

Nitrogen $(\mathrm{N})$ is the mineral nutrient required in the highest amount in plants [4]. It contributes approximately $2 \%$ of dry plant matter and exerts the greatest nutrient influence (up to $50 \%$ ) on the growth and yield of plants under different environmental conditions [5-6]. And it is crucial for the biosynthesis of amino acids, proteins, nucleic acids, etc. [7]. The absorption and utilization of $\mathrm{N}$ by plants under normal temperatures have been clarified. Plant roots absorb $\mathrm{N}$ primarily as nitrate $\left(\mathrm{NO}_{3}{ }^{-}\right)$and ammonium $\left(\mathrm{NH}_{4}{ }^{+}\right)$, especially $\mathrm{NO}_{3}{ }^{-}$for terrestrial plants [8]. The $\mathrm{NO}_{3}{ }^{-}$absorbed by plants should first be reduced to $\mathrm{NH}_{4}{ }^{+}$ before it could be metabolized. Reduction of $\mathrm{NO}_{3}{ }^{-}$to $\mathrm{NH}_{4}{ }^{+}$is catalyzed by nitrate reductase (NR) and nitrite reductase (NiR) [9]. Among them, NR is considered to be the rate-limiting step in nitrogen 
assimilation, and it catalyzes the nitrate-to-nitrite reduction process in plants [10]. It has been extensively demonstrated that NR and NiR activity can be detected in many tissues of plants (i.e. root, stem, cotyledon, inflorescence stalks, flowers, petiole, and leaf etc.) [11-14]. The main tissues that nitrate reduction took place in different plant species were different, mainly in the shoots, such as leaves, or petioles.

The absorption and transportation of nitrate and ammonium in plants were mediated by nitrate transporters (NRTs) and ammonium transporters (AMTs) respectively [15]. Four families of nitratetransporting proteins have been identified so far: nitrate transporter 1 family (NRT1), nitrate transporter 2 family (NRT2), the chloride channel family (CLC), and slow anion channel-associated homologues (SLAC1/SLAH) [16]. And the ammonium transporter gene family of vascular plants consists of two clades, AMT and MEP [17]. Many studies have shown that regulation of nitrate uptake and transport is often highly correlated with changes in expression of relevant transporter genes [18-19].

In many crop species, especially those originated from tropical and subtropical region, low temperature restricts uptake capacity of the root and distribution of nutrient elements in the shoot, especially depressed the uptake, translocation and metabolism of $\mathrm{NO}_{3}{ }^{-}$and $\mathrm{NH}_{4}{ }^{+}$, and then the plant growth and products were inhibited [20-21]. Low-temperature stress decreased plant height, root length, leaf area, dry mass accumulation and the strong seedling index, chlorophyll contents, photosynthesis, leaf and root nutrient contents, antioxidant enzymatic activities, and hormone accumulation in cucumber seedling [22]. Low root zone temperatures decreased the fresh weight, chlorophyll content, and antioxidant activity compared to optimum temperature, while the phenols of shoot and NR activity increased [23]. Long term (2-4 weeks) exposure to low root-zone temperature induced nitrate accumulation in roots and inhibited $\mathrm{N}$ transport via xylem [24]. Suboptimal root-zone temperatures led to a significant reduction in nitrate uptake rate [25].

The uptake of inorganic nitrogen forms was favoured by warm temperatures, especially nitrate [26]. Lowering growth temperature decreased $\mathrm{N}$ translocation more strongly than uptake, as the result, the $\mathrm{N}$ concentration in root increased [27]. However, previous studies mainly focused on the changes in physiological characteristics under low temperature, for example, the activities of nitrogen assimilation enzymes, and $\mathrm{N}$ concentrations in different plant tissues, etc. The effects of low temperature on the expression of NRTs and AMTs in higher plants were largely unknown. Furthermore, stable nitrogen isotope has always been the most important method in the study of nitrogen absorption and transportation. This method could only study the absorption and distribution of $\mathrm{N}$ in a period of time, and it is difficult to monitor the dynamic transport of nitrogen. So, there was no effective technology to study where nitrogen transport is stuck at low temperature before.

In recent years the Non-invasive Micro-test Technology (NMT) provides a new way to detect ion velocity in living plant tissue more directly [28]. The development and application of $\mathrm{NO}_{3}{ }^{-}$and $\mathrm{NH}_{4}{ }^{+}$sensors for NMT provide convenience for the detection of $\mathrm{NO}_{3}{ }^{-}$and $\mathrm{NH}_{4}{ }^{+}$uptake and transportation in plants by intuitively monitoring the net flow rate of the ions [29-30]. The purpose of this study, therefore, was to 
study the effects of low temperature on the absorption and transportation of $\mathrm{NO}_{3}{ }^{-}$and $\mathrm{NH}_{4}{ }^{+}$on the premise that the plant is regarded as a whole by using the new NMT technology, combined with ${ }^{15} \mathrm{~N}$ isotope tracing and qPCR technology.

We found that low temperature reduced the net $\mathrm{NO}_{3}{ }^{-}$flux rate in root hair zone and vascular bundles of cucumber seedlings, while enhanced the net $\mathrm{NH}_{4}{ }^{+}$flux rate in vascular bundles of midribs, lateral veins and shoot tips. In order to further understand the regulation of nitrogen transportation by low temperature, the uptake and distribution of ${ }^{15} \mathrm{~N}^{-\mathrm{NO}_{3}}{ }_{3}$ and ${ }^{15} \mathrm{~N}^{15} \mathrm{NH}_{4}{ }^{+}, \mathrm{NR}$ and NiR activities and gene expressions, relative expression of nitrate transporter (NRT) and ammonium transporter (AMT) were all measured under normal temperature (NT) treatment and low temperature (LT) treatment respectively. The results could help us to further understand the absorption and transport mechanism of nitrogen in thermophilic plants under low temperature, and provide technical support for the forms of nitrogen application in order to improve the growth and yield of the plant.

\section{Methods}

\section{Experimental design}

All experiments in this study were conducted in controlled-environment chambers (Memmert ICH L260). The seeds of cucumber (Cucumis stivus L.) cultivar 'Xintai Mici', which was buyed from the China Vegetable Seed Technology CO., LTD (Beijing) were incubated in darkness until germination at $28^{\circ} \mathrm{C}$ and then grown on vermiculite-sand mixture $[1: 2$, volume/volume $(\mathrm{V} / \mathrm{V})]$ supplied with half-strength modified Hoagland nutrient solutions at $26^{\circ} \mathrm{C} / 17^{\circ} \mathrm{C}$ (day/night) [25]. The photosynthetic photon flux density (PPFD), photoperiod, and relative humidity $(\mathrm{RH})$ were $350 \mu \mathrm{mol} \cdot \mathrm{m}^{-1} \cdot \mathrm{s}^{-1}, 12 \mathrm{~h} / \mathrm{d}$, and $70 \%-80 \%$, respectively. When the cotyledons of seedlings fully expanded, the seedlings were supplied with whole strength modified Hoagland nutrient solution ( $\mathrm{pH}=6.0$ ) containing $4 \mathrm{mM} \mathrm{Ca}\left(\mathrm{NO}_{3}\right)_{2}, 5 \mathrm{mM} \mathrm{KNO}_{3}, 1 \mathrm{mM}$ $\mathrm{NH}_{4} \mathrm{NO}_{3}, 1 \mathrm{mM} \mathrm{KH}_{2} \mathrm{PO}_{4}, 2 \mathrm{mM} \mathrm{MgSO}_{4} \cdot 7 \mathrm{H}_{2} \mathrm{O}, 40 \mu \mathrm{M}$ EDTA-Fe, $4 \mu \mathrm{M} \mathrm{H}_{3} \mathrm{BO}_{3}, 2 \mu \mathrm{M} \mathrm{MnSO}_{4} \cdot 4 \mathrm{H}_{2} \mathrm{O}, 2 \mu \mathrm{M}$ $\mathrm{ZnSO}_{4} \cdot 7 \mathrm{H}_{2} \mathrm{O}, 1 \mu \mathrm{M} \mathrm{CuSO}_{4} \cdot 5 \mathrm{H}_{2} \mathrm{O}$, and $0.5 \mu \mathrm{M}\left(\mathrm{NH}_{4}\right)_{6} \mathrm{Mo}_{7} \mathrm{O}_{24} \cdot 4 \mathrm{H}_{2} \mathrm{O}$. When the second leaves fully expanded, the seedlings were used for the following experiments.

Net fluxes rate of $\mathrm{NO}_{3}{ }^{-}$and $\mathrm{NH}_{4}{ }^{+}$, activities of $\mathrm{NR}$ and $\mathrm{NiR}$, gene expression: The seedlings were divided into two groups, exposed to normal temperature (NT: $26^{\circ} \mathrm{C}$ ) and low temperature (LT: $\left.8^{\circ} \mathrm{C}\right)$ for 5 hours separately. During the treatment, the light intensity and $\mathrm{RH}$ were the same as the seedling growth conditions. Then the seedlings were harvested for the tests.

Uptake of $\mathrm{NO}_{3}{ }^{-}$and $\mathrm{NH}_{4}{ }^{+}: \mathrm{NO}_{3}{ }^{-}$and $\mathrm{NH}_{4}{ }^{+}$uptake was measured according to the method described by Garnett et al. [31], with some modifications. Briefly, the seedlings were transplanted into rectangular hydroponic containers and supplied with whole-strength modified Hoagland nutrient solution one day prier the test. The containers were supplied with air bubblers to ensure adequate oxygen supply. On 
sampling days, plants were transferred to the same solution supplemented with ${ }^{15} \mathrm{~N}$-labelled $\mathrm{NO}_{3}{ }^{-}$or $\mathrm{NH}_{4}{ }^{+}$. The treatments were as follows:

(1) NT: $26{ }^{\circ} \mathrm{C}^{15} \mathrm{~N}$-labelled $\mathrm{NO}_{3}{ }^{-}\left({ }^{15} \mathrm{~N} 25 \%\right)$

(2) LT: $8{ }^{\circ} \mathrm{C}^{15} \mathrm{~N}$-labelled $\mathrm{NO}_{3}{ }^{-}\left({ }^{15} \mathrm{~N} 25 \%\right)$

(3) NT: $26^{\circ} \mathrm{C}^{15} \mathrm{~N}$-labelled $\mathrm{NH}_{4}{ }^{+}\left({ }^{15} \mathrm{~N} 100 \%\right)$

(4) LT: $8{ }^{\circ} \mathrm{C}{ }^{15} \mathrm{~N}$-labelled $\mathrm{NH}_{4}{ }^{+}\left({ }^{15} \mathrm{~N} 100 \%\right)$

After 5 hours of exposure, the seedlings were harvested for the determination of ${ }^{15} \mathrm{~N}$ content.

\section{Net fluxes rate of $\mathrm{NO}_{3}{ }^{-}$and $\mathrm{NH}_{4}{ }^{+}$measurement}

Net $\mathrm{NO}_{3}{ }^{-}$and $\mathrm{NH}_{4}{ }^{+}$flux rate in root hair zone, main root, stem, petiole, midrib, lateral vein, and shoot tip were detected using the non-invasive micro-test (NMT) system (Younger USA LLC, Amherst, MA 01002, USA) by Xuyue (Beijing) Sci. \& Tech. Co., Ltd., Beijing, China. The method referred to Lei et al. [32] with some modification. Samples were immersed in a petri dish containing $10-20 \mathrm{~mL}$ solution $(1.625 \mathrm{mM}$ $\mathrm{Ca}\left(\mathrm{NO}_{3}\right)_{2}, 0.25 \mathrm{mM} \mathrm{NH}_{4} \mathrm{NO}_{3}, 0.1 \mathrm{mM} \mathrm{MgSO}_{4}, 0.3 \mathrm{mM} \mathrm{MES} ; \mathrm{pH}=6.0$ ) for 10 min to reduce the influence of incision exudate on ion fluxes, then transferred to another petri dish containing fresh solution for steadystate $\mathrm{NO}_{3}{ }^{-}$and $\mathrm{NH}_{4}{ }^{+}$fluxes measurement. The measuring sites were pointed out in Fig. 1.

\section{$\mathrm{NO}_{3}{ }^{-}$and $\mathrm{NH}_{4}{ }^{+}$uptakes measurement}

$\mathrm{NO}_{3}{ }^{-}$and $\mathrm{NH}_{4}{ }^{+}$uptakes were determined following the protocols described by Garnett et al.[31]. Five hours after the treatment, roots were rinsed for $2 \mathrm{~min}$ in the identical and unlabeled modified Hoagland nutrient solution. The root surface was dried with absorbent paper. In addition, root, stem, cotyledon, $1^{\text {st }}$ petiole, $1^{\text {st }}$ blade, $2^{\text {nd }}$ petiole, $2^{\text {nd }}$ blade, and shoot tip were also sampled. All the samples were defoliated at $105^{\circ} \mathrm{C}$, and dried to constant weight at $55^{\circ} \mathrm{C}$. Then the samples were weighted and ground to a fine powder. Total nitrogen and ${ }^{15} \mathrm{~N}$ contents were measured using Continuous Flow-Isotope Ratio Mass Spectroscopy (CF-IRMS) united with vario PYRO cube with IsoPrime 100 [33].

\section{Detection of NR and NiR activities}

Root, stem, cotyledon, $1^{\text {st }}$ petiole, $1^{\text {st }}$ blade, $2^{\text {nd }}$ petiole, $2^{\text {nd }}$ blade, and shoot tip were sampled for the measurement of the nitrate reductase activity (NRA) and nitrite reductase activity (NiRA) according to Glaab [34] and Rajasekhar \& Mohr [35], respectively.

\section{Quantitative real-time PCR analysis}




\section{The samples were excised and frozen in liquid nitrogen and stored at $-80^{\circ} \mathrm{C}$ for the detection of gene expressions of nitrate transporter family genes (CsNRT1.1, CsNRT1.2a CsNRT1.2c, CsNRT1.3, CsNRT1.4a CsNRT1.4b, CsNRT1.5a CsNRT1.5c, CsNRT1.7 CsNRT1.10), chloride channel protein family genes (CsCLCa CsCLCg), slow anion channel-associated homologues (CSSLAH1 CsSLAH4), ammonium transporter family genes (CsAMT1.2a CsAMT1.2c, CsAMT2, CsAMT3.3), NR family genes (CsNR1 CsNR3), and NiR gene (CsNiR).}

Total RNA was extracted using RNAprep pure Plant Kit (TANGEN, Beijing, China) according to the manufacturer's instructions. The concentration of RNA was quantified by spectrophotomatrical measurement at $\lambda=260 \mathrm{~nm}$, and its integrity was checked on agarose gels [25]. First strand cDNA was synthesize using FastQuant RT Kit (TANGEN, Beijing, China) according to the manufacturer's instructions. The CDNA was then analyzed by qRT-PCR using Hieff qPCR SYBR Green Master Mix (11203ES03, YEASEN) on ABI 7500 Real Time PCR System (Applied BioSystems) [36]. Transcripts of the TIP41 (PP2A phosphatase activator, GW881871) were used to standardize the cDNA samples for different genes, because its expression is insensitive to low temperature [37]. Specific primers were designed using the Primer Premier 5 software [38] and the cucumber genome database [1]. Oligonucleotides list was described in Additional file 1.

\section{Data analysis}

Analysis of variance (two-way ANOVA) was performed using Least-Significant Difference (LSD) test. All statistically significant differences were identified as $P \otimes 0.05$, and Graphpad Prism 5 was applied for graphical presentation.

\section{Results}

Net $\mathrm{NO}_{3}{ }^{-}$and $\mathrm{NH}_{4}{ }^{+}$flux rate

In our first set of analysis, we found that $\mathrm{LT}\left(8^{\circ} \mathrm{C}\right)$ treatment significantly depressed the net $\mathrm{NO}_{3}{ }^{-}$flux rate in root hair zones and in the vascular bundle of other detection sites. The net $\mathrm{NO}_{3}{ }^{-}$influx rate in the root hair zone of $\mathrm{LT}\left(8^{\circ} \mathrm{C}\right)$ treatment was reduced to $19.3 \%$ of the $\mathrm{NT}\left(26^{\circ} \mathrm{C}\right)$ treatment. The net $\mathrm{NO}_{3}{ }^{-}$eflux rate in the vascular bundles of main roots, stems, petioles, midribs, lateral veins, and shoot tips were reduced to $36.2 \%, 11.7 \%, 11.0 \%, 21.5 \%, 7.6 \%$, and $23.1 \%$ of the NT $\left(26^{\circ} \mathrm{C}\right)$ treatment, respectively (Fig. 2$)$. This indicated that low temperature inhibited the uptake and upward transport of nitrate.

However, compared with the net $\mathrm{NO}_{3}{ }^{-}$flux rate, the change of net $\mathrm{NH}_{4}{ }^{+}$flux rate under $\mathrm{LT}$ treatment was different. The net $\mathrm{NH}_{4}{ }^{+}$influx rate in the root hair zone of $\mathrm{LT}\left(8^{\circ} \mathrm{C}\right)$ treatment was reduced to $68.7 \%$ of the 
NT $\left(26^{\circ} \mathrm{C}\right)$ treatment. The net $\mathrm{NH}_{4}{ }^{+}$eflux rate in the vascular bundles of main roots, stems and petioles under $\mathrm{LT}\left(8^{\circ} \mathrm{C}\right)$ treatment were reduced to $37.6 \%, 9.4 \%$, and $14.5 \%$ of $\mathrm{NT}\left(26^{\circ} \mathrm{C}\right)$ treatment, respectively (Fig. 3). While the net $\mathrm{NH}_{4}{ }^{+}$flux rate in the vascular bundles of midribs, lateral veins and shoot tips increased to $160.9 \%, 303.0 \%$, and $164.1 \%$ of NT $\left(26^{\circ} \mathrm{C}\right)$ treatment, respectively.

Compared with the net $\mathrm{NO}_{3}{ }^{-}$flux rate, the net $\mathrm{NH}_{4}{ }^{+}$flux rate of detection sites were much lower under NT treatment, but significantly higher in lateral vein and shoot tip under LT treatment. This indicated that the inhibition of net $\mathrm{NO}_{3}{ }^{-}$flux rate at low temperature was more serious than that of net $\mathrm{NH}_{4}{ }^{+}$flux rate.

\section{$\mathrm{N}$ uptake per plant, $\mathrm{N}$ concentration and $\mathrm{N}$ distribution in different tissues of the seedling}

In order to further explore the above phenomenon, the effects of low temperature on the uptake and distribution of $\mathrm{NO}_{3}{ }^{-}$and $\mathrm{NH}_{4}{ }^{+}$in plants was studied by isotope tracer method. Compared with NT treatment, $\mathrm{NO}_{3}{ }^{-}{ }^{-} \mathrm{N} \mathrm{NH}_{4}{ }^{+}-\mathrm{N}$ and total $\mathrm{N}$ uptake per plant under $\mathrm{LT}$ treatment decreased $78.1 \%, 58.8 \%$ and $72.6 \%$, respectively (Table 1). After $\mathrm{LT}$ treatment, the ratio of $\mathrm{NO}_{3}{ }^{-} \mathrm{N} /$ total $\mathrm{N}$ decreased significantly, while the ratio of $\mathrm{NH}_{4}{ }^{+} \mathrm{N} /$ total $\mathrm{N}$ increased significantly. This indicated that low temperature decreased $\mathrm{NO}_{3}{ }^{-}$ and $\mathrm{NH}_{4}{ }^{+}$uptake significantly, especially $\mathrm{NO}_{3}{ }^{-}$.

After 5 hours of $\mathrm{LT}$ treatment, the $\mathrm{NO}_{3}{ }^{-}-\mathrm{N}$ contents in the root, stem, cotyledon, $1^{\text {st }}$ petiole, $1^{\text {st }}$ blade, $2^{\text {nd }}$ petiole, $2^{\text {nd }}$ blade, and shoot tip were reduced to $33.8 \%, 13.7 \%, 15.8 \%, 6.8 \%, 18.8 \%, 8.2 \%, 14.4 \%$, and $10.6 \%$ of NT treatment, respectively. While the $\mathrm{NH}_{4}{ }^{+}-\mathrm{N}$ contents in the root, stem, cotyledon, $1^{\text {st }}$ petiole, $1^{\text {st }}$ blade, $2^{\text {nd }}$ petiole, $2^{\text {nd }}$ blade, and shoot tip were reduced to $78.3 \%, 43.0 \%, 29.7 \%, 23.4 \%, 30.4 \%, 24.6 \%$, $23.7 \%$, and $11.0 \%$ of NT treatment, respectively (Fig. 4). This result was consistent with Fig. 2-3.

Table $1 \mathrm{NO}_{3}{ }^{-} \mathrm{N}, \mathrm{NH}_{4}{ }^{+}-\mathrm{N}$, and total $\mathrm{N}$ uptake of per cucumber seedlings exposed to $26^{\circ} \mathrm{C}$ and $8^{\circ} \mathrm{C}$ for $5 \mathrm{~h}$.

\begin{tabular}{|c|c|c|c|c|c|}
\hline Treatment & $\begin{array}{l}\mathrm{NO}_{3}{ }^{-}-\mathrm{N} \text { uptake } \\
\text { ( } \mu \text { mol per } \\
\text { plant) }\end{array}$ & $\begin{array}{l}\mathrm{NH}_{4}{ }^{+}-\mathrm{N} \text { uptake } \\
\text { ( } \mu \text { mol per } \\
\text { plant) }\end{array}$ & $\begin{array}{l}\text { Total N uptake } \\
\text { ( } \mu \text { mol per } \\
\text { plant) }\end{array}$ & $\begin{array}{l}\mathrm{NO}_{3}{ }^{-}-\mathrm{N} / \text { total } \\
\mathrm{N} \\
(\%)\end{array}$ & $\begin{array}{l}\mathrm{NH}_{4}{ }^{+}-\mathrm{N} / \text { total } \\
\mathrm{N} \\
(\%)\end{array}$ \\
\hline $\mathrm{NT}\left(26^{\circ} \mathrm{C}\right)$ & $\begin{array}{l}229.60 \pm 12.13 \\
\text { a }\end{array}$ & $92.13 \pm 6.60 \mathrm{a}$ & $\begin{array}{l}321.73 \pm 18.73 \\
a\end{array}$ & $\begin{array}{l}71.37 \pm 3.78 \\
a\end{array}$ & $\begin{array}{l}28.63 \pm 1.86 \\
b\end{array}$ \\
\hline $\operatorname{LT}\left(8^{\circ} \mathrm{C}\right)$ & $50.33 \pm 3.00 b$ & $37.93 \pm 2.33 b$ & $88.27 \pm 5.33 b$ & $\begin{array}{l}57.02 \pm 3.36 \\
b\end{array}$ & $\begin{array}{l}42.98 \pm 2.53 \\
a\end{array}$ \\
\hline
\end{tabular}

Note: Total $\mathrm{N}$ refers to $\mathrm{NO}_{3}{ }^{-}-\mathrm{N}$ plus $\mathrm{NH}_{4}{ }^{+}-\mathrm{N}$. Values were means $\pm \mathrm{SE}(\mathrm{n}=3)$. Different lowercase letters indicate significant differences $(P<0.05)$.

As shown in Fig. 5, exposure of cucumber seedlings to low temperature resulted in a significant increase in not only $\mathrm{NO}_{3}{ }^{-} \mathrm{N}(24.8 \%)$ but also $\mathrm{NH}_{4}{ }^{+}-\mathrm{N}(26.0 \%)$ distribution proportion in roots. In other words, $\mathrm{LT}$ 
treatment significantly reduced the distribution ratio of $\mathrm{NO}_{3}{ }^{-}-\mathrm{N}$ and $\mathrm{NH}_{4}{ }^{+}-\mathrm{N}$ in the shoot. This result indicated that low temperature inhibited the transportation of $\mathrm{NO}_{3}{ }^{-}$and $\mathrm{NH}_{4}{ }^{+}$from root to shoot, and resulted in the accumulation of nitrogen in root.

The distribution proportion of $\mathrm{NO}_{3}{ }^{-}-\mathrm{N}^{-}$and $\mathrm{NH}_{4}{ }^{+}-\mathrm{N}$ in blade, stem, cotyledon, and other aerial tissues all decreased under LT treatment. Among the detection aerial tissues, the proportion of $\mathrm{NO}_{3}{ }^{-} \mathrm{N}$ distribution in stems, $1^{\text {st }}$ petioles, $1^{\text {st }}$ blades, $2^{\text {nd }}$ petioles, $2^{\text {nd }}$ blades and shoot tips of $L T$ treatment was $61.8 \%, 32.7 \%$, $85.4 \%, 38.2 \%, 66.9 \%$, and $47.6 \%$ of that of $\mathrm{NT}$ treatment, respectively. $\mathrm{Th} \mathrm{NH}_{4}{ }^{+} \mathrm{-N}$ distribution ratios in stems, $1^{\text {st }}$ petioles, $1^{\text {st }}$ blades, $2^{\text {nd }}$ petioles, $2^{\text {nd }}$ blades, and shoot tips treated with $8^{\circ} \mathrm{C}$ was $103.5 \%$, $59.2 \%, 73.3 \%, 61.0 \% 58.7 \%$, and $26.2 \%$ of those treated with $26^{\circ} \mathrm{C}$, respectively. This indicated that low temperature decreased the $\mathrm{NO}_{3}{ }^{-} \mathrm{N}$ distribution in petioles, stems and shoot tips more seriously than that in blades. While the effects of low temperature on the $\mathrm{NH}_{4}{ }^{+}-\mathrm{N}$ distribution in stems and petioles were almost the same, except that the proportion of $\mathrm{NH}_{4}{ }^{+}-\mathrm{N}$ distribution in stems increased under low temperature.

\section{Gene expression of CsNRTs, CsCLCs,CsSLAHs, and CsAMTs in petioles and midribs}

The effects of low temperature on the transcription levels of CSNRTS, CSCLCs, and CsAMTs were shown in Fig.6. The results showed that exposure of cucumber seedlings to low temperature decreased the relative expression of CSNRT1.4a in petioles and midribs, and CSAMT3.3 in midribs, whereas significantly enhanced the expression levels of CsNRT1.1, CsNRT1.3, CsNRT1.7, CsNRT1.8, CsCLCa, CsCLCe, CsAMT1.2c in petioles and midribs, CsNRT1.2b, CsAMT1.2a, and CsAMT1.2b in midribs.

The expression of CsNRT1.2a, CsNRT1.5a, CsNRT1.10, CsCLCC, CsCLCd, CsAMT2, and CsAMT3.3 in petioles and midribs, CsNRT1.2b, CsNRT1.4a, CsNRT1.4b, CsCLCa, CsCLCb, CsAMT1.2a and CsAMT1.2b in petioles were not significantly affected by low temperature (Fig. 6). The relative expression of CsNRT1.2c, CsNRT1.5b, CsNRT1.5c, CsNRT1.9, CsSLAH1 4, CsCLCf, CsCLCg, CsAMT1.1a, and CSAMT1.1b in petioles and midribs of the seedlings were much lower than the genes shown in Fig. 6 . So we didn't mention their relative expressions in this article.

\section{$\mathrm{NRA}_{\max }, \mathrm{NRA}_{\text {act }}$ NiRA in stems and petioles, gene expressions of CsNRs and CsNiR}

NR and NiR catalyze the nitrate-to-nitrite and nitrite-to-ammonium reduction process in plants, respectively $[10,39]$. $\mathrm{NRA}_{\max }$ can reflect the amount of enzyme protein indirectly, and $\mathrm{NRA}_{\text {act }}$ indicates actual NR activity in situ [40]. After 5 hours LT treatment, NRA $A_{\max }$ in roots were depressed significantly (61.5\% of NT treatment), while NRA max $_{\text {in }}$ in stems, petioles and midribs increased significantly (Fig. 7A). There was no significant difference in $\mathrm{NRA}_{\max }$ in blades between the two treatments.

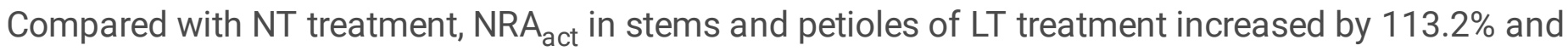

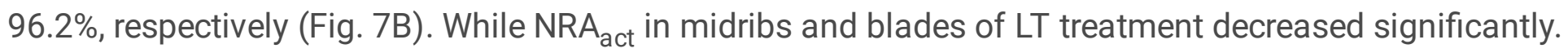


There was no significant difference in NRA $\mathrm{act}_{\text {int }}$ in roots between NT and LT treatment. Except for midribs, NiR activity in roots, stems, petioles and blades was not significantly decreased by LT treatment (Fig. 7C).

Cucumber sativus has 3 NR family genes (CsNR1, CsNR2, and CsNR3) according to Reda et al. [41]. Among them, the relative expression of CsNR1 in roots were much higher than that in other organs (Fig. $8 \mathrm{~A})$. Its expression in roots, stems, petioles, and midribs of cucumber were down-regulated by low temperature significantly. While it's expression in blades was not affected significantly by LT treatment. The relative expression of CsNR2 in leaves (petioles, midribs and blades) were higher than that in roots and stems, and low temperature up-regulated the expression of CsNR2 in leaves (Fig. 8B). The relative expression of $C s N R 2$ in roots was down-regulated by LT treatment, while the expression in stems was not affected significantly. High expression of CsNR3 was also found in leaves too, especially in blades. The relative expression of CsNR3 in blade of NT and LT treatment was 284 and 355 times higher than that in stems, respectively. LT treatment increased it's expression in all the detected tissues significantly (Fig. 8C). These results suggested that $C s N R 1$ may be the dominant gene of NR in cucumber roots, and $C s N R 3$ may be the dominant gene in cucumber leaves. CsNR2 and CsNR3 may play a leading role together in stem and petiole.

Compared with the CsNRs, the difference of relative expression of CsNiR in different tissues was small (Fig. 8D). LT treatment enhanced the expression of CsNiR in petioles, midribs, and blades. The highest expression of $C s N i R$ was observed in roots in both NT and LT treatment, but not affected by low temperature.

\section{Discussion}

$\mathrm{NO}_{3}{ }^{-} \mathrm{N}$ and $\mathrm{NH}_{4}{ }^{+}-\mathrm{N}$ are the main nitrogen sources of cucumber. Compared with single $\mathrm{NO}_{3}{ }^{-}-\mathrm{N}$ source or single $\mathrm{NH}_{4}{ }^{+}-\mathrm{N}$ source, compound nitrogen source is more conducive to the nitrogen absorption and growth of plants [42]. Plant preference for $\mathrm{NO}_{3}{ }^{-} \mathrm{N}$ or $\mathrm{NH}_{4}{ }^{+}-\mathrm{N}$ is related to species and influenced by environmental conditions and growth stages [43-45]. Cucumber is a temperature sensitive protected horticultural crop. The response of nitrogen uptake and transportation to low temperature is one of the important manifestations of temperature reduction affecting plant growth.

\section{Low temperature inhibited $\mathrm{NO}_{3}{ }^{-}$absorption more than $\mathrm{NH}_{4}{ }^{+}$}

The results on Ceratonia siliqua showed that root temperature affected the kinetic parameters of nitrate uptake more than those of ammonium uptake [46]. For barley plants, Q10 temperature coefficients for $\mathrm{NO}_{3}{ }^{-}$was quite bigger than that for $\mathrm{NH}_{4}{ }^{+}$[47]. Under low temperature the $\mathrm{NO}_{3}{ }^{-}$uptake in Secale cereale and Brassica napus reduced [48]. Our result showed that compared with the cucumber seedlings grown under suitable temperature $\left(26^{\circ} \mathrm{C}\right)$, the $\mathrm{NO}_{3}{ }^{-}$and $\mathrm{NH}_{4}{ }^{+}$absorbed by cucumber seedlings under low temperature $\left(8^{\circ} \mathrm{C}\right)$ decreased significantly, especially $\mathrm{NO}_{3}{ }^{-}$(Table 1$)$, indicating that the inhibition of low 
temperature on $\mathrm{NO}_{3}{ }^{-}$absorption was greater than $\mathrm{NH}_{4}{ }^{+}$absorption. Deceasing air temperature could severely inhibit total $\mathrm{N}$ absorption, mainly in $\mathrm{NO}_{3}{ }^{-} \mathrm{N}$.

This may be due to the fact that, cucumber prefers to absorb $\mathrm{NO}_{3}{ }^{-} \mathrm{N}$ rather than $\mathrm{NH}_{4}{ }^{+}-\mathrm{N}$ under normal environmental conditions. The uptake of $\mathrm{NO}_{3}{ }^{-}$is energy dependent [49]. And the energy requirements for absorption and assimilation of $\mathrm{NO}_{3}{ }^{-}$are several fold higher than those of $\mathrm{NH}_{4}{ }^{+}$[50]. With the occurrence of low temperature stress, the energy absorbed and utilized by leaves decreased significantly [51]. So after $\mathrm{LT}$ treatment, the uptake of $\mathrm{NO}_{3}{ }^{-}$by roots would be severely inhibited due to limited energy.

\section{Low temperature inhibited $\mathrm{NO}_{3}{ }^{-}$and $\mathrm{NH}_{4}{ }^{+}$upward transportation and reduced $\mathrm{N}$ concentrations in the shoot}

The transport of nitrate was induced by $\mathrm{NO}_{3}{ }^{-}$, regulated by the feedback of cell nitrogen level, and promoted by photosynthesis [52]. Previous studies showed that low temperature severely reduced xylem sap transport in cucumber [53]. Laine reported that low temperature decreased xylem $\mathrm{N}$ translocation, and resulted $\mathrm{N}$ accumulation in the roots of Secale cereale and Brassica napus [48]. Our results conformed that low temperature not only inhibited the uptake of $\mathrm{NO}_{3}{ }^{-} \mathrm{N}^{-}$and $\mathrm{NH}_{4}{ }^{+} \mathrm{N}$, but also inhibited the upward transportation of them. Compared with NT treatment, the distribution proportion of $\mathrm{NO}_{3}{ }^{-} \mathrm{N}^{-}$and $\mathrm{NH}_{4}{ }^{+}-\mathrm{N}^{-}$in the shoot under LT treatment decreased from $74.0 \%$ and $70.4 \%$ to $45.2 \%$ and $44.3 \%$, respectively (Fig. 5). It means that under low temperature a grater proportion of $\mathrm{NO}_{3}{ }^{-} \mathrm{N}$ and $\mathrm{NH}_{4}{ }^{+}-\mathrm{N}$ absorbed by cucumber seedlings were accumulated in the root, instead of being transported to the shoot. This indicated that low temperature seriously inhibited the transportation of nitrogen from root to shoot. Our results also showed that the inhibition degree of $\mathrm{NO}_{3}{ }^{-} \mathrm{N}$ upward transportation was almost the same as that of $\mathrm{NH}_{4}{ }^{+}-\mathrm{N}$ by low temperature.

Low temperature significantly depressed the $\mathrm{NO}_{3}{ }^{-}-\mathrm{N}$ and $\mathrm{NH}_{4}{ }^{+}-\mathrm{N}$ concentrations in all the detection sites of cucumber seedlings (Fig. 4). Under $26^{\circ} \mathrm{C}$ treatment, the $\mathrm{NO}_{3}{ }^{-} \mathrm{N}$ concentrations in the detection sites of cucumber seedlings were significantly higher than $\mathrm{NH}_{4}{ }^{+}-\mathrm{N}$ concentrations, indicating that $\mathrm{NO}_{3}{ }^{-} \mathrm{N}$ is the main nitrogen form used by cucumber seedlings. This was the same as most terrestrial plants [8]. Recently Anwar [22] reported that low temperature reduced $\mathrm{N}$ content in roots of cucumber seedlings, but didn't reduce $\mathrm{N}$ contents in the shoot significantly. This may be due to the different detection methods. The total $\mathrm{N}$ contents were detected in his paper, while the ${ }^{15} \mathrm{~N}$ concentrations were detected in our experiment.

Under $\mathrm{LT}$ treatment the $\mathrm{NO}_{3}{ }^{-} \mathrm{N}$ concentrations in root, cotyledon and blade of cucumber seedlings were significantly higher than $\mathrm{NH}_{4}{ }^{+}-\mathrm{N}$ concentrations, while the $\mathrm{NO}_{3}{ }^{-} \mathrm{N}$ concentrations in stems and petioles $\left(7^{\text {st }}\right.$ petiole and $2^{\text {nd }}$ petiole) were significantly lower than $\mathrm{NH}_{4}{ }^{+}-\mathrm{N}$ concentrations (Fig. 4). In contrast, under low temperature the $\mathrm{NH}_{4}{ }^{+}-\mathrm{N}$ distribution in stems increased from $3.68 \%$ to $3.81 \%$, while the $\mathrm{NO}_{3}{ }^{-} \mathrm{N}$ 
distribution in stems decreased from $4.63 \%$ to $2.86 \%$ (Fig. 5). Compared with NT treatment, under low temperature the decrease of $\mathrm{NH}_{4}{ }^{+}-\mathrm{N}$ distribution in the $1^{\text {st }}$ petioles and $2^{\text {nd }}$ petioles $(40.8 \%$, and $38.6 \%$, respectively) was significantly lower than that of $\mathrm{NO}_{3}-\mathrm{N}(92.9 \%$, and $91.6 \%$, respectively) (Fig. 5). This indicated that the distribution of $\mathrm{NO}_{3}{ }^{-} \mathrm{N}$ in vascular bundles was more significantly affected by low temperature than $\mathrm{NH}_{4}{ }^{+} \mathrm{N}$.

\section{Low temperature enhanced the net $\mathrm{NH}_{4}{ }^{+}$eflux rate in the vascular bundles of midrib, lateral vein and shoot tip of cucumber seedlings}

The net $\mathrm{NO}_{3}{ }^{-}$and $\mathrm{NH}_{4}{ }^{+}$flux rate detected by NMT method showed that the $\mathrm{NO}_{3}{ }^{-}$flux rate in the vascular bundles of cucumber seedlings was reduced significantly under low temperature. And the net $\mathrm{NH}_{4}{ }^{+}$flux rate in the vascular bundles of main root, stem and petiole decreased sharply as expected. What we found interesting was that, the net $\mathrm{NH}_{4}{ }^{+}$flux rate in midrib, lateral vein, and shoot tip of cucumber seedlings increased significantly under low temperature (Fig. 4), which was inverse change in net $\mathrm{NO}_{3}{ }^{-}$ flux rate, and was not consistent with the distribution proportion of ${ }^{15} \mathrm{~N}^{-\mathrm{NH}_{4}}{ }^{+}$in leaf and shoot tip (Fig. 5).

\section{Low temperature increased the NR activity in stems and petioles}

Under low temperature, on the premise that the total amount of $\mathrm{NO}_{3}{ }^{-}-\mathrm{N}$ and $\mathrm{NH}_{4}{ }^{+}-\mathrm{N}$ absorbed by the seedlings and transported from root to shoot decreased, how to explain the increase of net $\mathrm{NH}_{4}{ }^{+}$flux rate in midrib, lateral vein and shoot tip? Then, the morphological changes of nitrogen in the process of transport were studied..

NR was the key rate limiting enzyme in nitrate reduction [10]. In higher plants the activity of NR is regulated at both phosphorylation and transcriptional level [54]. Under low temperature, $\mathrm{NRA}_{\max }$ in roots decreased, while NRA act didn't change significantly, indicating that low temperature reduced the amount of enzyme protein, but had no significant effect on the apparent activity of the enzyme (Fig. 7). Therefore,

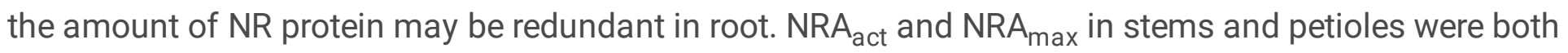
increased significantly, indicating that the change of enzyme protein content was consistent with the change of enzyme apparent activity, and $\mathrm{NRA}_{\mathrm{act}}$ in stems and petioles were regulated by low temperature at transcriptional level mainly. Compared with LT treatment, under low temperature NRA $A_{\text {max }}$ in midribs

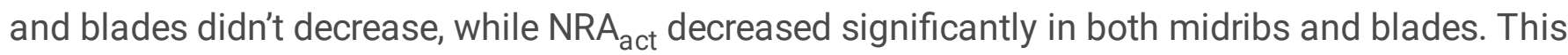
indicated that the regulation of low temperature on $\mathrm{NRA}_{\mathrm{act}}$ in midrib and blade may be mainly through protein phosphorylation. In all, low temperature had no effect on NRA act in roots, but significantly increased $\mathrm{NRA}_{\text {act }}$ in stems and petioles of cucumber seedlings. This may result in the fact that more $\mathrm{NO}_{3}{ }^{-}$ was reduced to $\mathrm{NH}_{4}{ }^{+}$during its transportation in stems and petioles.

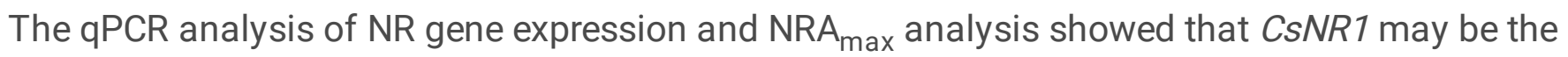
dominant gene of NR in cucumber roots (Fig. 7A and Fig. 8A). CsNR3 may be the dominant gene in 
cucumber leaves (Fig. 7A and Fig. 8C). In stems and petioles CsNR2 and CsNR3 may play a leading role together (Fig. 7A and Fig. 8B-C).

\section{Different changes of NRT and AMT family gene expression patterns under low temperature}

Nitrate uptake by plants is regulated by transcriptional regulation [55]. Two environmental conditions, temperature and nutrient concentration, were found to significantly influence the gene expression of nutrient transporters [56]. With the increase of temperature, the relative expression of AMT family genes showed regular changes, while the maximum expression of different genes in AMT family emerged at different temperatures. There are few studies on the function of cucumber nitrogen transporter so far [5759]. And little information about the regulatory pathways that involved in the effect of low temperature on the expression of these genes has been reported.

In this experiment, the relative expression of 34 nitrogen transporter genes in petioles and midribs of cucumber seedlings treated with $26^{\circ} \mathrm{C}$ and $8^{\circ} \mathrm{C}$ respectively were detected. NRT1.1 (NPF6.3) was regarded to be a dual-affinity nitrate transporter participated in nitrate absorption and transport [60-61]. Our results showed that the expression of CSNRT1.1 in midribs of cucumber seedlings was up-regulated by low temperature, indicating that CsNRT1.1 may not be the dominant gene in nitrate transportation in cucumber. AtNRT1.8 in Arabidopsis was related to stress-induced nitrate redistribution [62]. The relative expression of CsNRT1.8 in petioles and midribs were up-regulated by low temperature. This may allow more nitrate to be transported to the root, thus reducing the net ion flux rate in petiole and midrib. AtNRT1.4 and AtNRT1.7 family genes were responsible for nitrate flow to petioles and leaves [63-64]. In cucumber, we found two homologous genes of AtNRT1.4 from NCBI, CsNRT1.4a and CsNRT1.4b. After 5 $\mathrm{h}$ of LT treatment the expression of CSNRT1.4a in petioles and midribs was down-regulated, while the expression of $C s N R T 1.4 b$ was up-regulated. The different response of their relative expression to low temperature may be due to their different functions. CsNRT1.7 was involved in nitrate recycling in cucumber [57]. Under low temperature CsNRT1.7 in petioles and midribs was up-regulated. This may reduce nitrate up-transport to the leaves to some extent.

AtCLCs were reported to play a role in nitrate assimilation of plants. AtClCa and AtCLCe have been shown to be critical for nitrate transport into the vacuoles [65-66]. The relative expression of CsCLCa and CsCLCe in petioles and midribs of cucumber seedlings were significantly up-regulated caused by low temperature. This may lead to more nitrate storage in vacuoles under low temperature.

The AMT1 subfamily of Arabidopsis plays an important role in the stage of ammonium absorption [67]. And the MEP subfamily (AtAMT2) may play a role in the transport of ammonium from apoplast to symplast [68]. In our experiment up-regulated CsAMT1.2a 1.2c in midribs possibly contributed to the higher net $\mathrm{NH}_{4}^{+}$flux rate under low temperature.

\section{Biological significance of the increase of net $\mathrm{NH}_{4}{ }^{+}$fluxes in the vigorous growing tissue under low temperature}


Plants will transfer nutrients to young tissues and seeds when unsuitable environment comes [69]. This is the result of the long evolution of plants. In this experiment, on the premise that the absorption and upward transportation of $\mathrm{NH}_{4}{ }^{+}$decreased under low temperature, the net $\mathrm{NH}_{4}{ }^{+}$flux rate in midribs, lateral veins and shoot tips increased significantly. This could be due to the transformation of $\mathrm{NO}_{3}{ }^{-}$during transportation. More $\mathrm{NO}_{3}{ }^{-}$was reduced to $\mathrm{NH}_{4}{ }^{+}$during it's upward transportation under low temperature. This could greatly reduce the energy consumption in the transportation process. According to Han et al. [70], under low temperature stress, the content of $\mathrm{NO}_{3}{ }^{-} \mathrm{N}$ and the $\mathrm{NR}$ activities in tomato leaves significantly decreased, while the $\mathrm{NH}_{4}{ }^{+} \mathrm{N}$ content significantly increased. Under drought stress, the $\mathrm{NH}_{4}{ }^{+}$ nutrition can limit the effect of water deficit by osmotic adjustment and can limit oxidative damage [71]. So, assumed that $\mathrm{NH}_{4}{ }^{+}$plays a role in the prevention of stress-induced peroxidation, the increase of $\mathrm{NH}_{4}{ }^{+}$ content in leaves and young tissues is not only beneficial to the utilization of nitrogen nutrition, but also to the improvement of stress tolerance of plants. Kant [72] believed that improving nitrate uptake and transport would enhance plant growth, resulting in improved crop yields. In the future, research on improving the nitrogen nutrition status of plants by improving the ratio of $\mathrm{NO}_{3}{ }^{-}-\mathrm{N}^{-} \mathrm{NH}_{4}{ }^{+}-\mathrm{N}$ under low temperature needs to be carried out.

\section{Conclusion}

In conclusion, we found that low temperature reduced the uptake and distribution of ${ }^{15} \mathrm{~N}_{-} \mathrm{NH}_{4}{ }^{+}$and ${ }^{15} \mathrm{~N}-$ $\mathrm{NO}_{3}{ }^{-}$in leaves and shoot tips of cucumber seedlings, reduced the net $\mathrm{NO}_{3}{ }^{-}$flux rate in root hair zone and vascular bundles of cucumber seedlings, while enhanced the net $\mathrm{NH}_{4}{ }^{+}$flux rate in vascular bundles of midribs, lateral veins and shoot tips, as presented in Fig. 9. In line with this, the relative expression of CSNRT1.4a in petioles and midribs was down-regulated, while the expressions of CsAMT1.2a 1.2c in midribs were up-regulated by low temperature. So, the higher net $\mathrm{NH}_{4}{ }^{+}$flux rate in leaves and young tissues may be due to the higher $\mathrm{NR}_{\text {act }}$ in stems and petioles, which was mainly regulated at transcriptional level by low temperature. Our results provided first evidence that cucumber seedlings reduced energy consumption of nitrate transportation by reducing more $\mathrm{NO}_{3}{ }^{-}$to $\mathrm{NH}_{4}{ }^{+}$under low temperature. Given the importance of cucumber as a vegetable crop in greenhouse, this study may not only help further understand the low temperature tolerance of thermophilic plants, but also help improve the winter cultivation techniques of protected vegetables in greenhouse.

\section{Abbreviations}

NT: normal temperature, $26^{\circ} \mathrm{C}$; LT: low temperature, $8^{\circ} \mathrm{C}$; NMT: the non-invasive micro-test technology; NR: nitrate reductase; NiR: nitrite reductase; NRA: the nitrate reductase activity; NiRA: the nitrite reductase activity; $\mathrm{NRA}_{\text {act }}$ : the actual nitrate reductase activity; $\mathrm{NRA}_{\text {max }}$ : the maximum nitrate reductase activity; NRT: nitrate transporter; NRT1: nitrate transporter 1 family; NRT2: nitrate transporter 2 family; CLC: the 
chloride channel family; SLAH: slow anion channel-associated homologues; AMT: ammonium transporter.

\section{Declarations}

\section{Acknowledgements}

Not applicable.

\section{Funding}

This work was financially supported by funds from the National Key Research and Development Program of China (2018YFD0201207, 2019YFD1000300), the National Natural Science Foundation of China (NSFC) (31801909), the Earmarked fund for Modern Agro-industry Technology Research System in China (CARS-25-C-01), the Science and Technology Innovation Program of the Chinese Academy of Agricultural Sciences (CAASASTIP-IVFCAAS), and the Key Laboratory of Horticultural Crop Biology and Germplasm Innovation, Ministry of Agriculture, China. Funding body had no role in the design of the study and collection, analysis, interpretation of data and in writing the manuscript.

\section{Availability of data and materials}

The datasets supporting the results of this article are included within the article and the additional files.

\section{Authors' contributions}

$X C Y, Y S L$ and YML conceived and designed the research. YML performed most of the experiments. LQB, MTS, and JW made important comments on design of the trial, the article writing, and the revisions. YSL, YML, LQB and MTS analyzed the data. YML wrote the first draft of the manuscript. XCY and YSL improved the first draft of the manuscript. All of the authors read and approved the final manuscript.

\section{Ethics approval and consent to participate}

Not applicable.

\section{Consent for publication}

Not applicable.

\section{Competing interests}

The authors declare that they have no competing interests.

\section{References}


1. Li Q, Li H, Huang W, et al. A chromosome-scale genome assembly of cucumber (Cucumis sativus). Giga Science. 2019;8(6):giz072.

2. Yagcioglu $M$, Jiang $B$, Wang $P$, et al. QTL mapping of low temperature germination ability in cucumber. Euphytica. 2019;215:84.

3. Khan TA, Fariduddin Q, Yusuf M. Low-temperature stress: is phytohormones application a remedy? Environmental Science and Pollution Research. 2017;24(27):21574-21590.

4. Lejay L , Gojon A. Root nitrate uptake. Advances in Botanical Research. 2018;87:139-169.

5. Williams LE, Miller AJ. Transporters responsible for the uptake and partitioning of nitrogenous solutes. Annual Review of Plant Physiology \& Plant Molecular Biology. 2001;52:659-688.

6. Stewart WM, Dibb DW, Johnston AE, et al. The contribution of commercial fertilizer nutrients to food produc-tion. Agron J. 2005;97(1):1-6.

7. Masclaux-Daubresse C, Daniel-Vedele F, Dechorgnat $\mathrm{J}$, et al. Nitrogen uptake, assimilation and remobilization in plants: challenges for sustainable and productive agriculture. Annals of Botany. 2010;105(7):1141-1157.

8. Goron T L, Raizada M N. Biosensor-based spatial and developmental mapping of maize leaf glutamine at vein-level resolution in response to different nitrogen rates and uptake/assimilation durations. BMC Plant Biology. 2016;16(1):230-240.

9. Warner RL, Kleinhofs A. Genetics and molecular biology of nitrate metabolism in higher plants. Physiologia plantarum. 1992;85(2):245-252.

10. Yanagisawa S. Transcription factors involved in controlling the expression of nitrate reductase genes in higher plants. Plant Science. 2014;229:167-171.

11. Li XZ, Oaks A. The effect of light on the nitrate and nitrite reductases in Zea mays. Plant Science. 1995;109(2):115-118.

12. Singh N, Pokhriyal TC. Nitrate reductase activity and nitrogen content in relation to seed source variation in Dalbergia sissoo seedlings. Journal of Tropical Forest Science. 2005;17(1):127-140.

13. Hassanpanah D. In vitro and in vivo screening of potato cuitivars against water stress by polyethylene glycol and potassium humate. Biotechnology. 2009;8(1):132-137.

14. Sakar FS, Arslan H, Kırmızıb S, et al. Nitrate reductase activity (NRA) in Asphodelus aestivus (Liliaceae): distribution among organs, seasonal variation and differences among populations. Flora (Jena). 2010;205(8):527-531.

15. Von Wittgenstein NJ , Le CH, Hawkins BJ , et al. Evolutionary classification of ammonium, nitrate, and peptide transporters in land plants. BMC Evolutionary Biology. 2014;14(1):11.

16. Wang YY, Hsu PK, Tsay YF. Uptake, allocation and signaling of nitrate. Trends Plant Sci. 2012;17(8): 458-467.

17. Mcdonald TR, Ward JM. Evolution of electrogenic ammonium transporters (AMTs). Frontiers in Plant Science. 2016;7:352. 
18. Ninnemann $\mathrm{O}$, Jauniaux JC, Frommer WB. Identification of a high affinity $\mathrm{NH}_{4}{ }^{+}$transporter from plants. Embo Journal. 1994;13(15): 3464-3471.

19. Huang NC, Liu KH, Lo HJ, et al. Cloning and functional characterization of an Arabidopsis nitrate transporter gene that encodes a constitutive component of low-affinity uptake. Plant Cell. 1999;11(8):1381-

20. Shimono H, Fujimura S, Nishimura T, et al. Nitrogen uptake by rice (Oryza sativa) exposed to low water temperatures at different growth stages. Journal of Agronomy and Crop Science. 2012;198(2):145-151.

21. Zhu XC, Song FB, Liu FL, et al. Carbon and nitrogen metabolism in arbuscular mycorrhizal maize plants under low-temperature stress. Crop and Pasture Science. 2015;66(1):62-70.

22. Anwar $A$, Yan Y, Liu Y, et al. 5-Aminolevulinic acid improves nutrient uptake and endogenous hormone accumulation, enhancing low-temperature stress tolerance in cucumbers. International Journal of Molecular Sciences. 2018;19: 3379.

23. Haghighi M, Mozafariyan M, Abdolahipour B. Effect of cucumber mycorrhiza inoculation under low and high root temperature grown on hydroponic conditions.J Crop Sci Biotechnol.2015;18:89-96.

24. Kim TH, Chun YT, Kim KY, et al. Root zone temperature effects on nitrate assimilation and xylem transport in hydroponically grown cucumber plants. Acta Horticulturae. 2002;588:59-62.

25. Bai L, Deng H, Zhang $X$, et al. Gibberellin is involved in inhibition of cucumber growth and nitrogen uptake at suboptimal root-zone temperatures. Plos One. 2016;11(5):e0156188.

26. Warren $C R$. Why does temperature affect relative uptake rates of nitrate, ammonium and glycine: $A$ test with Eucalyptus pauciflora. Soil Biology \& Biochemistry. 2009;41(4):778-784.

27. Yan Q, Duan Z, Mao J, et al. Effects of root-zone temperature and N, P, and K supplies on nutrient uptake of cucumber (Cucumis sativus) seedlings in hydroponics. Soil Science and Plant Nutrition. 2012;58(6):707-717.

28. Xu Y, Sun T, Yin LP. Application of non-invasive microsensing system to simultaneously measure both $\mathrm{H}^{+}$and $\mathrm{O}_{2}$ fluxes around the pollen tube. Journal of Integrative Plant Biology. 2006;48(7):823831.

29. Li S, Jiang F, Han Y, et al. Comparison of nitrogen uptake in the roots and rhizomes of Leymus chinensis. Biologia Plantarum. 2018;62(1):149-156.

30. Bai L, Ma X, Zhang G, et al. A receptor-like kinase mediates ammonium homeostasis and is important for the polar growth of root hairs in arabidopsis. Plant Cell. 2014;(4):1497-1511.

31. Garnett T, Conn V, Plett D, et al. The response of the maize nitrate transport system to nitrogen demand and supply across the lifecycle. New Phytologist. 2013;198(1):82-94.

32. Lei B, Huang Y, Sun J, et al. Scanning ion-selective electrode technique and X-ray microanalysis provide direct evidence of contrasting $\mathrm{Na}^{+}$transport ability from root to shoot in salt-sensitive cucumber and salt-tolerant pumpkin under $\mathrm{NaCl}$ stress. Physiologia Plantarum. 2014;152(4):738748. 
33. Agnihotri R, Kumar R, Prasad MVSN, et al. Experimental setup and standardization of a continuous flow stable isotope mass spectrometer for measuring stable isotopes of carbon, nitrogen and sulfur in environmental samples. Mapan. 2014;29(3):195-205.

34. Glaab J, Kaiser WM. Increased nitrate reductase activity in leaf tissue after application of the fungicide Kresoxim-methyl. Planta. 1999;207(3):442-448.

35. Rajasekhar VK, Mohr H. Appearance of nitrite reductase in cotyledons of the mustard (Sinapis alba) seedling as affected by nitrate, phytochrome and photooxidative damage of plastids. Planta. 1986;168(3):369-376.

36. Wang J, Ge P, Qiang L, et al. The mycobacterial phosphatase PtpA regulates the expression of host genes and promotes cell proliferation. Nature Communications. 2017;8:244.

37. Migocka M, Papierniak A. Identification of suitable reference genes for studying gene expression in cucumber plants subjected to abiotic stress and growth regulators. Molecular Breeding. 2011;28(3):343-357.

38. Lalitha S. Primer Premier 5. Biotech Software \& Internet Report. 2000.

39. Wu Y, Zhang W, Xu L, et al. Isolation and molecular characterization of nitrite reductase (RsNiR) gene under nitrate treatments in radish. Scientia Horticulturae. 2015;193:276-285.

40. Kaiser WM, Huber SC. Correlation between apparent activation state of nitrate reductase (NR), NR hysteresis and degradation of NR protein. Journal of Experimental Botany. 1997;48(312):1367-1374.

41. Reda M, Migocka M, Kłobus G. Effect of short-term salinity on the nitrate reductase activity in cucumber roots. Plant Science. 2011;180(6):783-788.

42. Hessini K, Issaoui K, Ferchichi $S$, et al. Interactive effects of salinity and nitrogen forms on plant growth, photosynthesis and osmotic adjustment in maize. Plant Physiol Biochem. 2019;139:171178.

43. Gherardi LA, Sala OE, Yahdjian L. Preference for different inorganic nitrogen forms among plant functional types and species of the Patagonian steppe. Oecologia. 2013;173(3):1075-1081.

44. Zhang C, Meng S, Li Y, et al. Nitrogen uptake and allocation in Populus simoniiin different seasons supplied with isotopically labeled ammonium or nitrate. Trees. 2016;30(6):2011-2018.

45. Zhang $H$, Zhao $X$, Chen $Y$, et al. Case of a stronger capability of maize seedlings to use ammonium being responsible for the higher ${ }^{15} \mathrm{~N}$ recovery efficiency of ammonium compared with nitrate. Plant and Soil. 2019;440:293-309.

46. Cruz C, Lips SH, Martins-Loução MA. Uptake of ammonium and nitrate by carob (Ceratonia siliqua) as affected by root temperature and inhibitors. Physiologia Plantarum. 1993;89(3):532-543.

47. Macduff $\mathrm{JH}, \mathrm{Hopper}$ MJ. Effects of root temperature on uptake of nitrate and ammonium ions by barley grown in flowing-solution culture. Plant and Soil. 1986;91(3):303-306.

48. Laine P, Bigot J, Ourry A, et al. Effects of low temperature on nitrate uptake, and xylem and phloem flows of nitrogen, in Secale cereale and Brassica napus L. New Phytologist. 1994;127(4):675-683. 
49. Bose B, Srivastava HS. Absorption and accumulation of nitrate in plants: Influence of environmental factors. Indian Journal of Experimental Biology. 2001;39(2):101-110.

50. Bloom AJ. Nitrogen dynamics in plant growth systems. Life Support \& Biosphere Science International Journal of Earth Space. 1996;3(1-2):35-41.

51. Ma J, Janouskova M, Ye L, et al. Role of arbuscular mycorrhiza in alleviating the effect of coldon the photosynthesis of cucumber seedlings. Photosynthetica. 2019;57(1):86-95.

52. O'Brien JA, Vega A, Bouguyon E, et al. Nitrate transport, sensing, and responses in plants. Molecular Plant. 2016;9(6):837-856.

53. Lee SH, Chung GC. Sensitivity of root system to low temperature appears to be associated with the root hydraulic properties through aquaporin activity. Scientia Horticulturae. 2005;105(1):1-11.

54. Huarancca Reyes T, Scartazza A, Pompeiano A, et al. Nitrate reductase modulation in response to changes in $\mathrm{C} / \mathrm{N}$ balance and nitrogen source in Arabidopsis. Plant \& Cell Physiology. 2018;59(6):1248-1254.

55. Plett DC, Holtham LR, Okamoto $M$, et al. Nitrate uptake and its regulation in relation to improving nitrogen use efficiency in cereals. Seminars in Cell \& Developmental Biology. 2018;74:97.

56. Fan $X, X u D$, Wang $D$, et al. Nutrient uptake and transporter gene expression of ammonium, nitrate, and phosphorus in Ulva linza: adaption to variable concentrations and temperatures. Journal of Applied Phycology. 2020;32(2):1311-1322.

57. Wu T, Qin Z, Fan L, et al. Involvement of 7 in nitrate recycling during senescence in cucumber. Journal of Plant Nutrition and Soil Science. 2014;177(5):714-721.

58. Li Y, Li J, Yan Y, et al. Knock-down of 1, a cucumber nitrate transporter, reduces nitrate uptake, root length, and lateral root number at low external nitrate concentration. Frontiers in Plant Science. 2018;9:722.

59. Hu X, Zhang J, Liu W, et al. (2020). 2 has a potential to regulate cucumber seedling growth in early nitrogen deficiency stress. Plant Molecular Biology Reporter. 2020;38:461-477.

60. Wen Z, Tyerman SD, Dechorgnat J, et al. Maize NPF6 proteins are homologs of Arabidopsis CHL1 that are selective for both nitrate and chloride. Plant Cell.2017;29(10):2581-2596.

61. Ji S, Ning Z. Molecular mechanism underlying the plant NRT1.1 dual-affinity nitrate transporter. Frontiers in Physiology. 2015;6: 386.

62. Li JY, Fu YL, Pike SM, et al. The Arabidopsis nitrate transporter 8 functions in nitrate removal from the xylem sap and mediates cadmium tolerance. Plant Cell. 2010;22(5):1633-1646.

63. Chiu CC, Lin CS, Hsia AP, et al. Mutation of a nitrate transporter, AtNRT1:4, results in a reduced petiole nitrate content and altered leaf development. Plant Cell Physiol. 2004;45(9):1139-1148.

64. Fan SC, Lin CS, Hsu PK, et al. The Arabidopsis nitrate transporter 7, expressed in phloem, is responsible for source-to-sink remobilization of nitrate. Plant Cell. 2009;21(9):2750-2761.

65. De Angeli A, Monachello D, Ephritikhine G, et al. The nitrate/proton antiporter AtCLCa mediates nitrate accumulation in plant vacuoles. Nature. 2006;442(7105): 939-942. 
66. Monachello D, Allot M, Oliva S, et al. Two anion transporters AtClCa and AtClCe fulfil interconnecting but not redundant roles in nitrate assimilation pathways. New Phytol. 2009;183(1): 88-94.

67. Loqué $\mathrm{D}$, Yuan L, Kojima $\mathrm{S}$, et al. Additive contribution of $A M T 1 ; 1$ and $A M T 1 ; 3$ to high-affinity ammonium uptake across the plasma membrane of nitrogen-deficient Arabidopsis Plant Journal. 2006;48(4):522-534.

68. Sohlenkamp C. Characterization of ArabidopsisAtAMT2, a high-affinity ammonium transporter of the plasma membrane. Plant Physiology. 2002;130(4):1788-1796.

69. Yusuke Y, Mikihisa U. Possible roles of strigolactones during leaf senescence. Plants. 2015;4(3):664677.

70. Han M, Cao B, Liu S, et al. Effects of rootstock and scion interaction on photosynthesis and nitrogen metabolism of grafted tomato seedlings leaves under low temperature stress. Acta Horticulturae Sinica. 2018;45 (5) ه897-

71. Pereira PN, Gaspar M, Smith JAC, et al. Ammonium intensifies CAM photosynthesis and counteracts drought effects by increasing malate transport and antioxidant capacity in Guzmania monostachia. Journal of Experimental Botany. 2018;69(8):1993-2003.

72. Kant S. Understanding nitrate uptake, signaling and remobilisation for improving plant nitrogen use efficiency. Semin Cell Dev Biol. 2018;74:89-96.

\section{Figures}




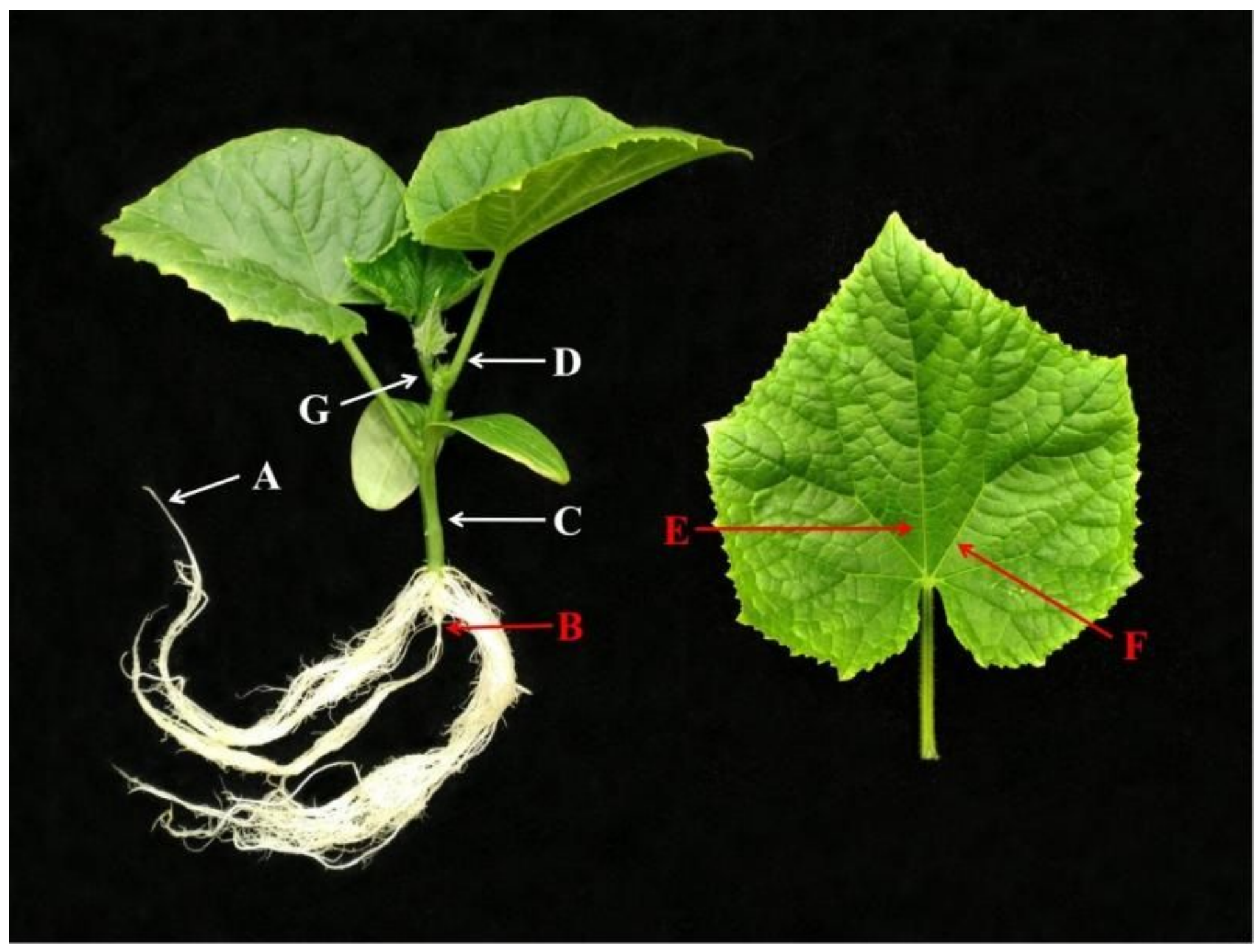

\section{Figure 1}

transferred to another petri dish containing fresh solution for steady-state $\mathrm{NO} 3$ - and $\mathrm{NH} 4+$ fluxes measurement. The measuring sites were pointed out in Fig. 1. 

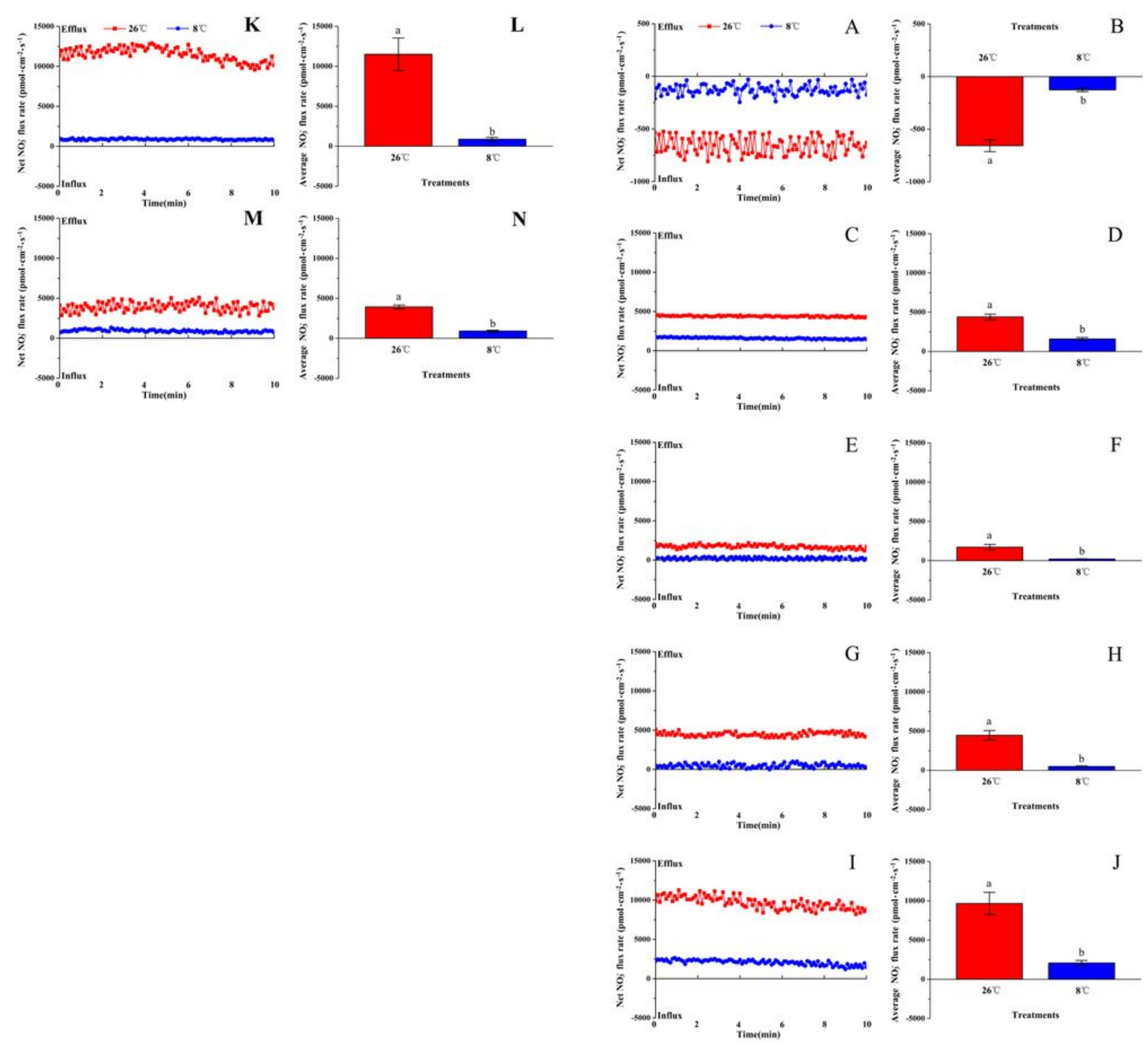

\section{Figure 2}

The net N03- eflux rate in the vascular bundles of main roots, stems, petioles, midribs, lateral veins, and shoot tips were reduced to $36.2 \%, 11.7 \%, 11.0 \%, 21.5 \%, 7.6 \%$, and $23.1 \%$ of the NT $\left(26{ }^{\circ} \mathrm{C}\right)$ treatment, respectively (Fig. 2). 

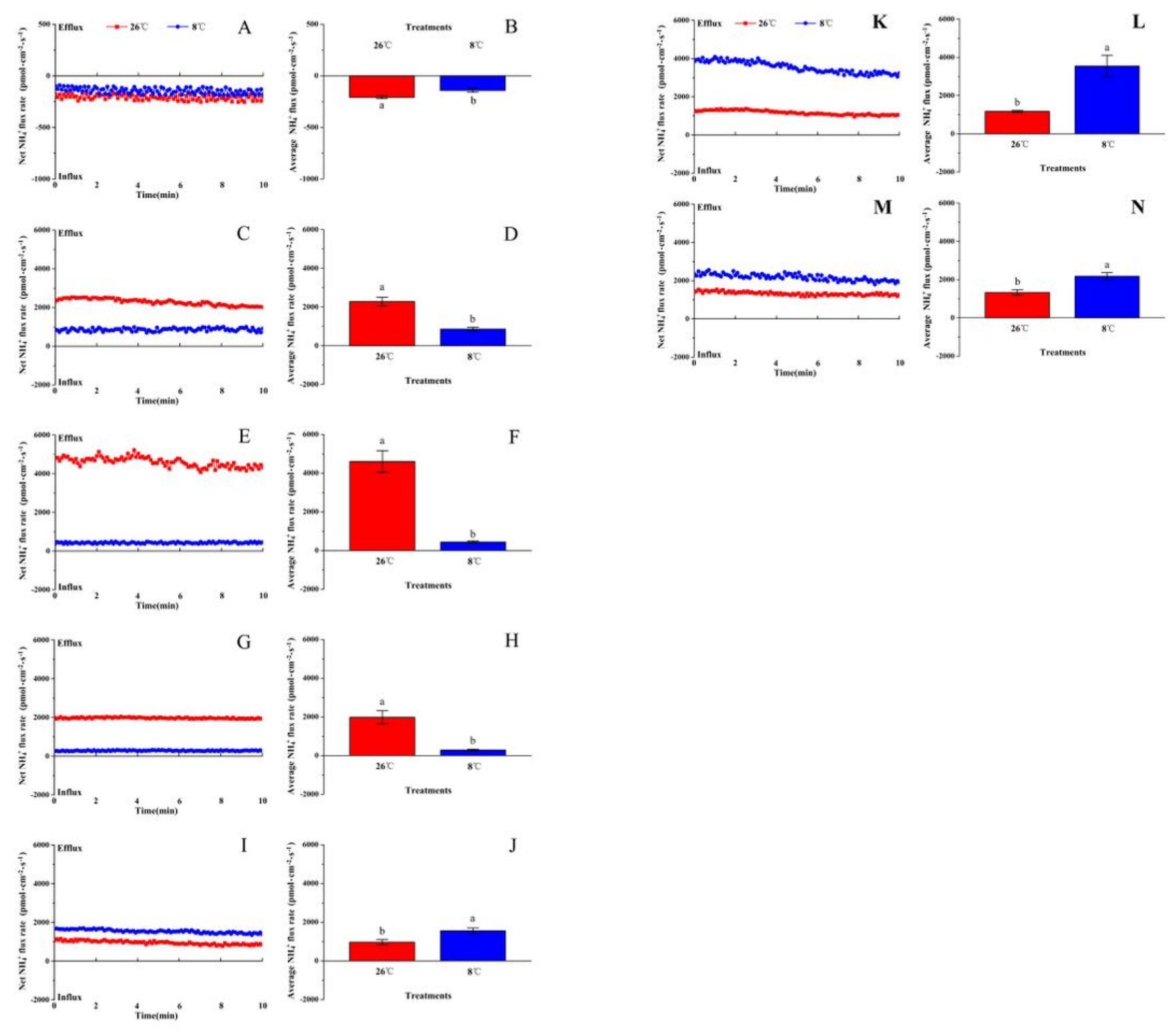

Figure 3

stems and petioles under $\mathrm{LT}\left(8^{\circ} \mathrm{C}\right)$ treatment were reduced to $37.6 \%, 9.4 \%$, and $14.5 \%$ of $\mathrm{NT}\left(26{ }^{\circ} \mathrm{C}\right)$ treatment, respectively (Fig. 3). 


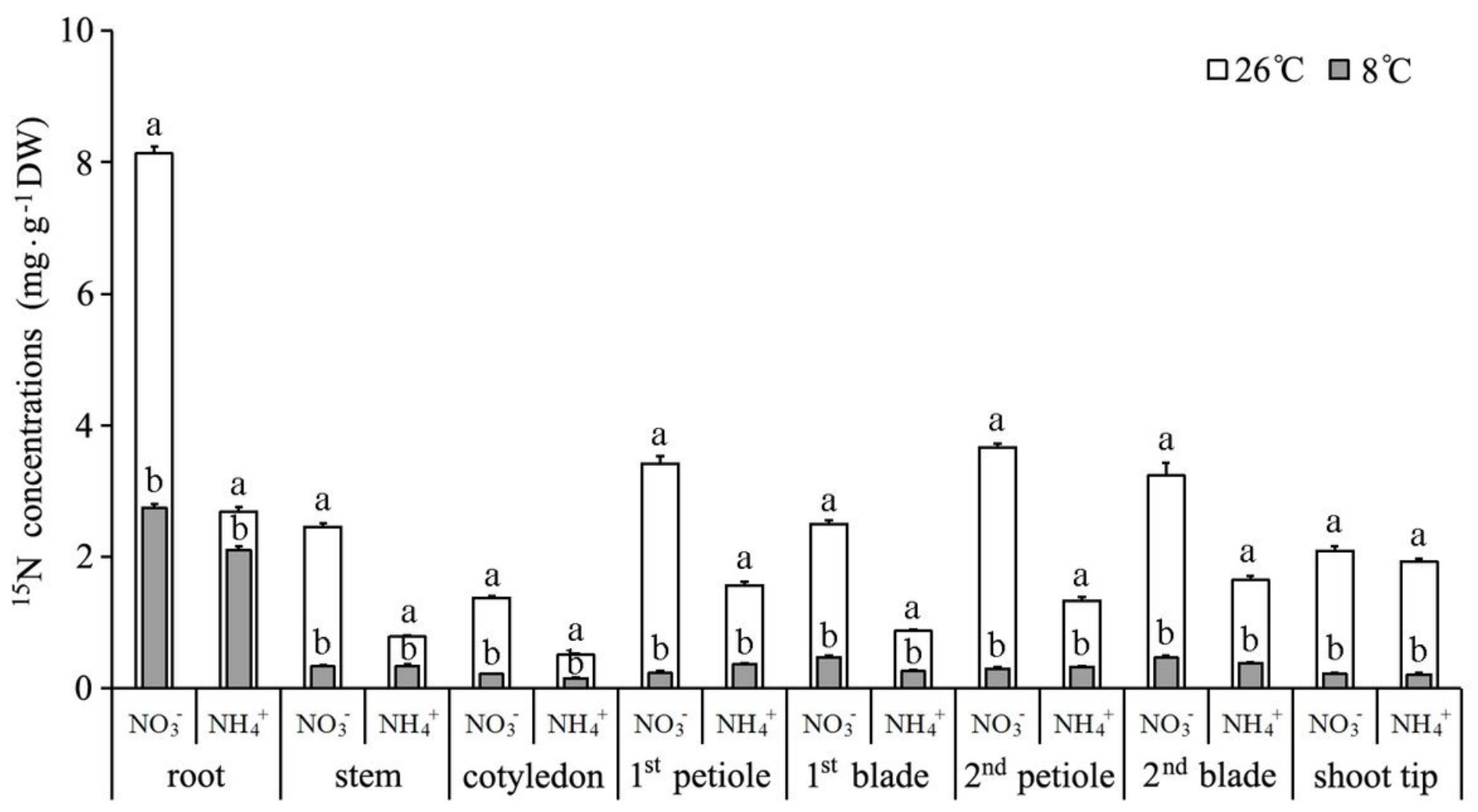

Figure 4

While the $\mathrm{NH} 4+-\mathrm{N}$ contents in the root, stem, cotyledon, 1 st petiole, 1 st blade, 2 nd petiole, $2 \mathrm{nd}$ blade, and shoot tip were reduced to $78.3 \%, 43.0 \%, 29.7 \%, 23.4 \%, 30.4 \%, 24.6 \%, 23.7 \%$, and $11.0 \%$ of NT treatment, respectively (Fig. 4). 

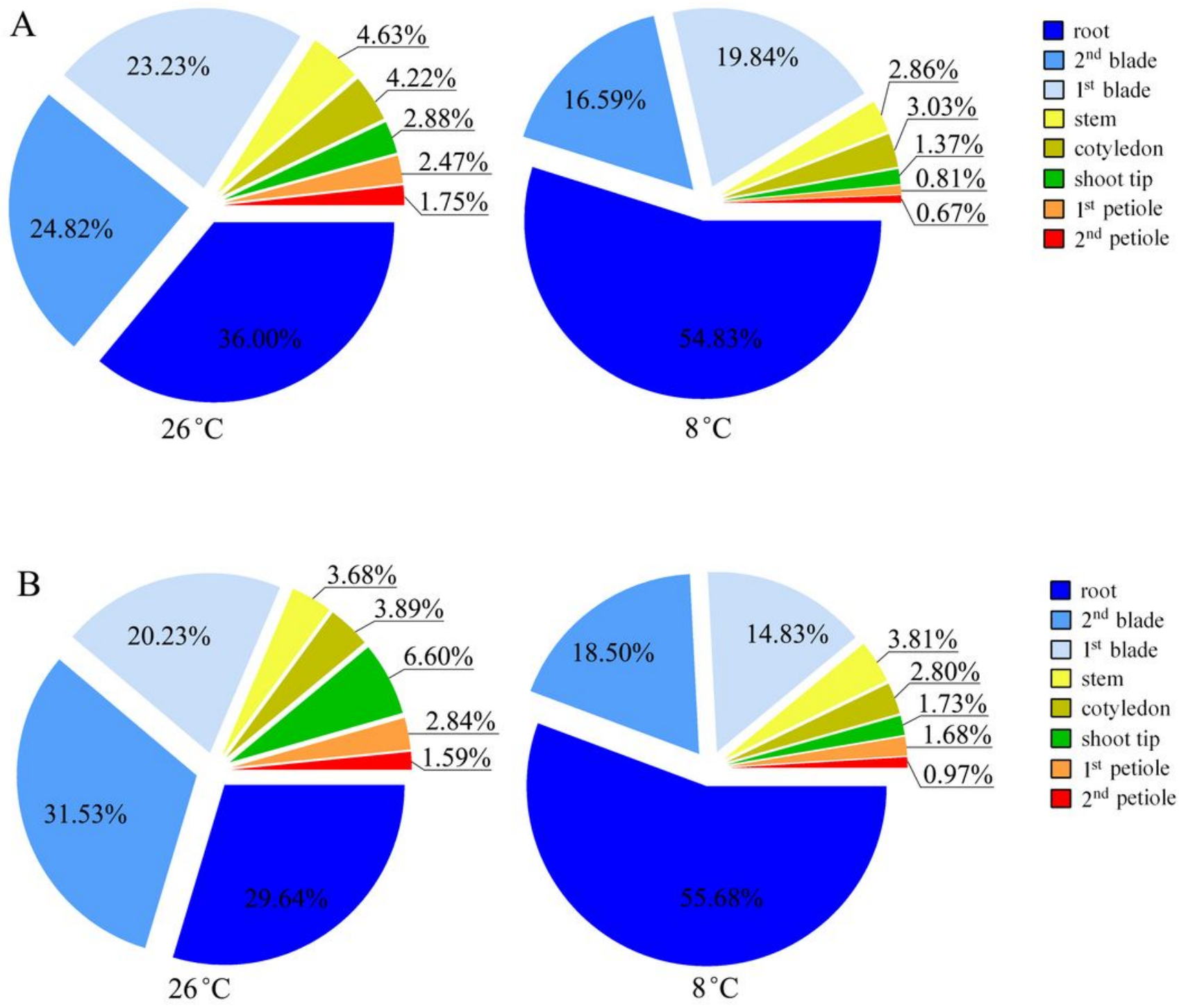

Figure 5

As shown in Fig. 5, exposure of cucumber seedlings to low temperature resulted in a significant increase in not only NO3-N (24.8\%) but also NH4+-N (26.0\%) distribution proportion in roots. 

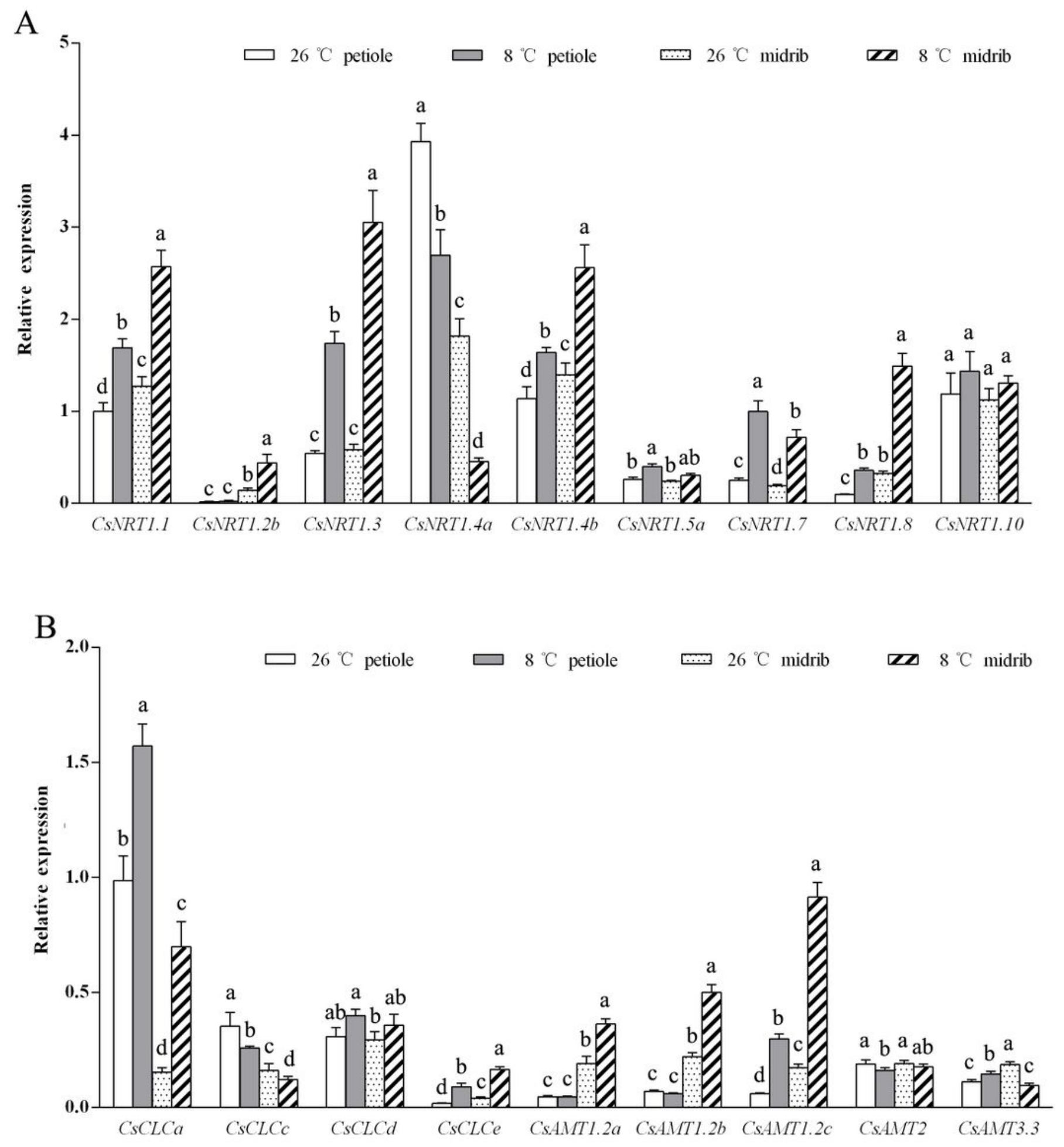

Figure 6

The effects of low temperature on the transcription levels of CsNRTs, CsCLCs, and CsAMTs were shown in Fig.6. 
A

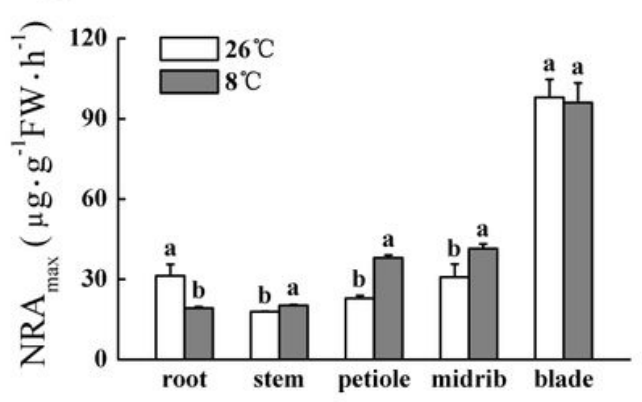

B

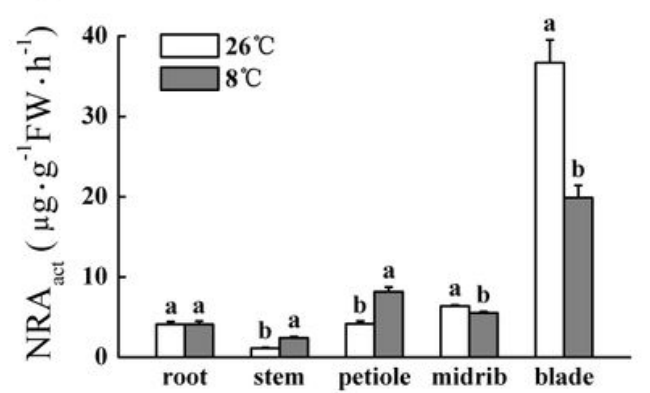

$\mathrm{C}$

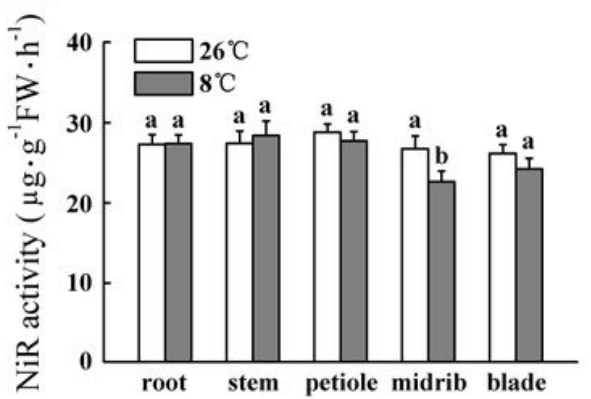

Figure 7

Except for midribs, NiR activity in roots, stems, petioles and blades was not significantly decreased by LT treatment (Fig. 7C).

A

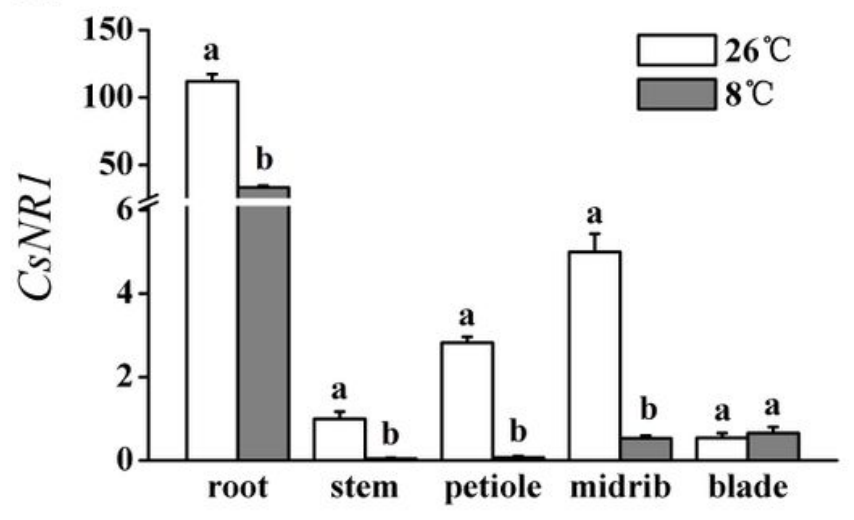

$\mathrm{C}$

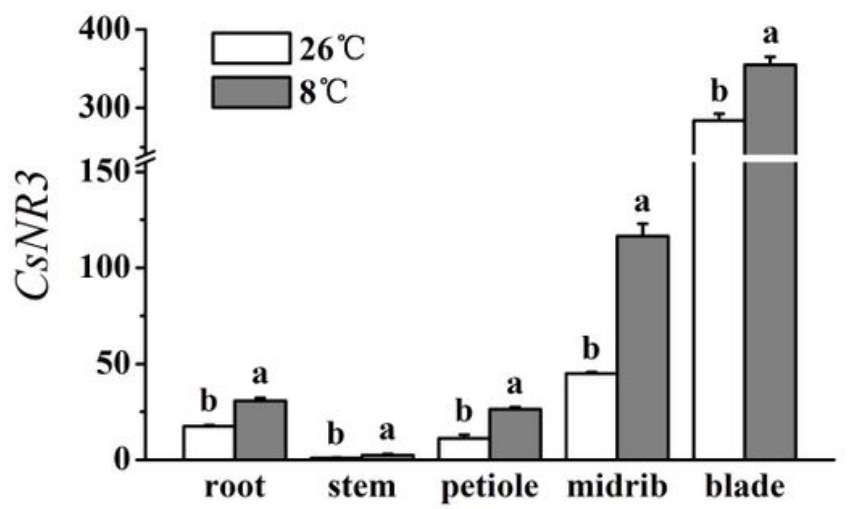

B

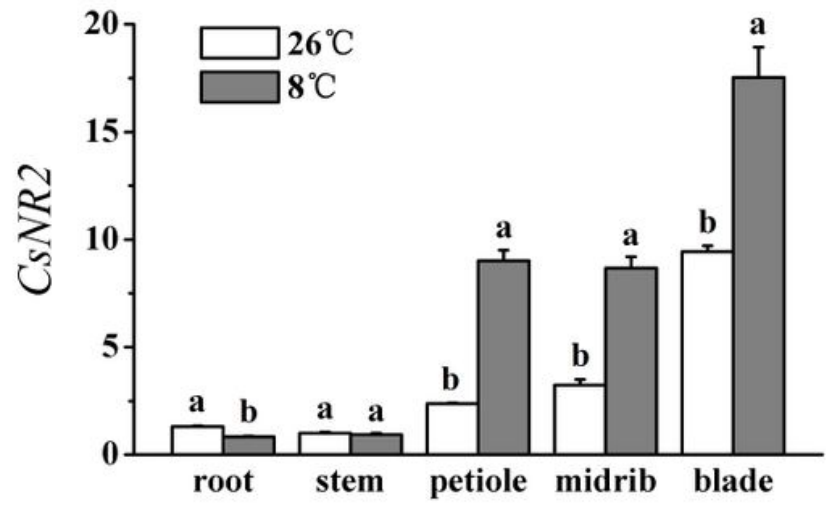

D

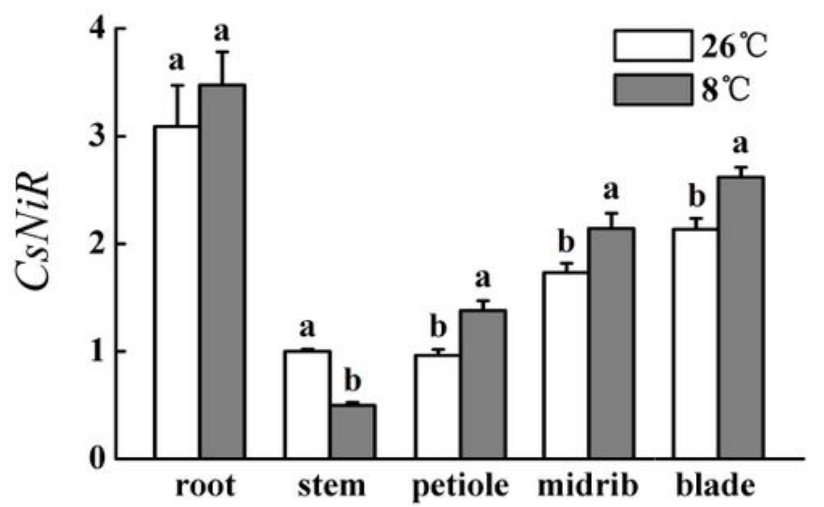

Figure 8

Compared with the CsNRs, the difference of relative expression of CsNiR in different tissues was small 


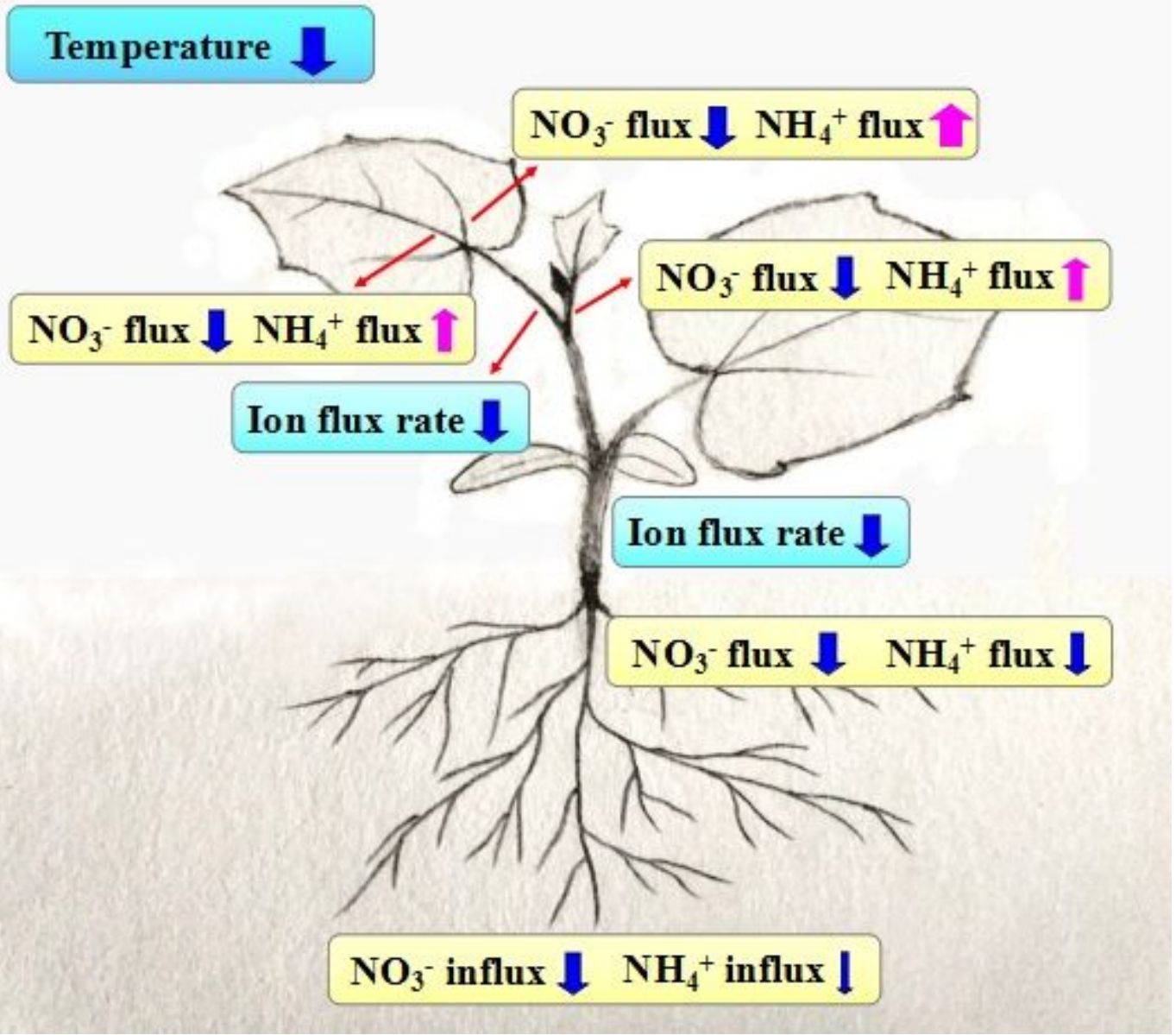

Figure 9

The net $\mathrm{NH} 4+$ flux rate in vascular bundles of midribs, lateral veins and shoot tips, as presented in Fig. 9.

\section{Supplementary Files}

This is a list of supplementary files associated with this preprint. Click to download.

- Additionalfile1.docx

- Additionalfile2.docx 